\title{
UPORABA TUĐE NEKRETNINE RADI IZVOĐENJA RADOVA
}

Lidija Bošnjaković, dipl. iur.*

\author{
UDK 347.232(497.5) \\ https://doi.org/10.30925/zpfsr.42.2.15 \\ Ur.: 27. veljače 2021. \\ Pr.: 5. srpnja 2021. \\ Stručni rad
}

\begin{abstract}
Sažetak
U radu se prikazuje korištenje instituta uporabe tuđe nekretnine radi izvođenja radova kao vlasničkoga prava u sudskoj praksi. Pritom je autorica nastojala upozoriti na najčešće probleme koji se pojavljuju u vođenju takvih postupaka, koji su se pokazali složenim s obzirom na obvezni sadržaj tužbenoga zahtjeva te nastojala dati odgovor na pojedina pravna pitanja.
\end{abstract}

Ključne riječi: uporaba tuđe nekretnine radi izvođenja radova; obveznik prava; ovlaštenik prava; naknada štete; primjerena naknada.

\section{UVOD}

Kada je riječ o pravu vlasništva uglavnom se govori o ovlastima koje to pravo daje svom nositelju, a koje se može opisati kao najšira ovlast koju neka osoba može imati u odnosu na neku stvar koja može biti predmetom vlasništva. To znači da se s tom stvari i koristima od nje čini što ga je volja te da svakoga drugog od toga isključi, odnosno da tu stvar posjeduje, koristi i njome raspolaže. ${ }^{1}$

Pritom se najčešće previdi da pravo vlasništva koje osigurava nositelju najšire ovlasti istodobno mu nameće i niz obveza i ograničenja koja su uređena zakonom i mogu mu se nametnuti samo uz pretpostavke i na način određen zakonom. Pri ograničavanju prava vlasništva treba poći od sadržaja čl. 3. i 48. Ustava Republike Hrvatske. ${ }^{2}$ Prema njemu je vlasništvo jednu od najviših vrijednosti ustavnoga poretka Republike Hrvatske, kao i pravo na mirno uživanje vlasništva koje je zajamčeno i odredbama Ustava RH i Protokolom broj 1. Konvencije za zaštitu ljudskih prava i temeljnih sloboda. ${ }^{3}$ Zadiranje u to pravo, sukladno s navedenim domaćim

* Lidija Bošnjaković, dipl. iur., sutkinja Županijskog suda u Zagrebu: lidija.bosnjakovic5@, gmail.com. ORCID: https://orcid.org/ 0000-0001-7517-9947.

1 Čl. 30 Zakona o vlasništvu i drugim stvarnim pravima, Narodne novine, br. 91/96., 68/98., 137/99., 22/00., 73/00., 114/01., 79/06., 141/06., 146/08., 38/09., 153/09., 90/10., 143/12., 152/14. (dalje: ZV).

2 Ustav Republike Hrvatske, Narodne novine, br. 56/90., 135/97., 8/98., 113/00., 124/00., 28/01., 41/01., 55/01., 76/10., 85/10., 5/14. (dalje: Ustav RH).

3 Europska konvencije za zaštitu ljudskih prava i temeljnih sloboda, Narodne novine, Međunarodni 
i međunarodnim aktima, dopušteno je samo ako je to predviđeno zakonom. Svako ograničenje prava vlasništva mora biti razmjerno naravi potrebe za ograničenjem u svakom slučaju (čl. 16. Ustava RH).

Jedno je od tih ograničenja i uporaba tuđe nekretnine radi izvođenja radova.

Uporaba tuđe nekretnine radi izvođenja radova susjedsko je pravo i u smislu čl. 100. ZV-a ovlast je vlasnika nekretnine (dalje: vlasnik povlasne nekretnine / ovlaštenik prava) da u svezi s izvršavanjem svoga prava vlasništva zahtijeva od osobe koja je vlasnik druge nekretnine (dalje: vlasnik poslužne nekretnine / obveznik prava) da u njegovu interesu trpi, propusti ili čini u odnosu na svoju nekretninu ono što je određeno zakonom. Konkretno da trpi uporabu svog zemljišta radi izvođenja radova postavljanja skele i sl. (čl. 107. ZV-a), na kojoj je nužno te radove izvesti i ako se to na drugi način ne može izvesti.

Budući da susjedska prava predstavljaju ograničenje prava vlasništva, na njih se primjenjuje i odredba iz čl. 31. ZV-a. Njome su uređena opća ograničenja prema kojima vlasništvo obvezuje i vlasnik je dužan pridonositi općem dobru i općenito u izvršavanju svoga prava dužan je postupati obzirno prema općim i tuđim interesima koji nisu protivni njegovu pravu.

Pritom je nužno poštovati opću odredbu iz čl. 1. ZV-a, koja se odnosi na pravo vlasništva i druga stvarna prava. U skladu s njom, pravo vlasništva protiv vlasnikove volje može se oduzeti ili ograničiti samo uz pretpostavke ili na način određen zakonom, kao i iz st. 4. istoga članka, da kada vlasnik mora što trpjeti ili propustiti vezano za njegove stvari, to treba i ovlaštenik drugoga stvarnog prava na istoj stvari koji svoje pravo izvodi iz njegova, ako što nije drugo određeno zakonom.

\section{ODNOS NAČELA OPĆEG OGRANIČENJA I OVLASTI UPORABE RADI IZVOĐENJA RADOVA}

Načelo općeg ograničenja obuhvaćeno je u čl. 31. ZV-a. Njime je propisano da vlasništvo obvezuje vlasnika da pridonosi općem dobru koje se očituje u tome da je u izvršavanju svog prava dužan postupati obzirno prema općim i tuđim interesima koji nisu protivni njegovu pravu.

Nadalje, propis općeg ograničenja ograničava sve vlasnike, a i druge, služiti se svojim pravom u cilju da drugome našteti ili da ga smeta.

Propis općeg ograničenja ukida ovlaštenje da svaki vlasnik zabrani tuđi zahvat u svoju stvar, kada je taj zahvat nužan radi otklanjanja štete koja nekom neposredno prijeti, a nerazmjerno je veća od one što iz toga zahvata proizlazi za vlasnika. U tom bi smislu obavljanje nužnih radova potrebnih za uporabu i korištenje povlasne nekretnine kada su istodobno nužni i za otklanjanje štete koja neposredno prijeti i nerazmjerno je veća od štete koja istodobno proizlazi za vlasnika poslužne nekretnine, omogućavalo primjenu propisa općeg ograničenja prava vlasništva. U tom slučaju

ugovori, br. 18/97., 6/99. - pročišćeni tekst, 8/99., 14/02., 13/03., 9/05., 1/06., 2/10. i 13/17. (dalje: Konvencija). Protokol broj 1. Konvencije za zaštitu ljudskih prava i temeljnih sloboda, Narodne novine, Međunarodni ugovori, br. 18/97., 6/99., 14/02, 13/03., 9/05., 1/06., 2/10. (dalje: Protokol 1). 
propis općeg ograničenja pruža veći opseg ovlasti budući da dopušta poduzimanje svih zahvata nužnih za otklanjanje štete uz navedene pretpostavke. Propis prava uporabe tuđe nekretnine radi izvođenja radova dopušta poduzimanje samo onih radova koji su nužni za uporabu i korištenje povlasne nekretnine koji se ne mogu izvesti na drugi način. Posljedica poduzimanja radnji na temelju općeg ograničenja prava prva vlasništva kao i na temelju ovlasti uporabe radi izvođenja radova jeste u oba slučaja dužnost naknade štete vlasniku poslužne nekretnine, dok kod ovlasti uporabe radova istom pripada i primjerena naknada.

Propis općeg ograničenja ukida ovlaštenje da svaki vlasnik zabrani tuđi zahvat u svoju stvar, čak i ako je riječ o tuđem zahvatu poduzetom na tolikoj visini ili dubini gdje on nema nikakva opravdana interesa da ih isključi.

Sadržajno, uporaba tuđe nekretnine radi izvođenja radova (dalje: uporaba radi izvođenja radova) u slučaju iz čl. 107. ZV-a ograničena je na izvođenje nužnih radova potrebnih za korištenje nekretnine ovlaštenika tog prava, uz uvjet da su ti radovi nužni $i$ da se ne mogu izvesti na druge načine.

S obzirom na navedeno, prema sadržaju prava vlasništva, bez postojanja općih i zakonskih ograničenja vlasnik ima isključivo pravo posjedovanja, korištenja i raspolaganja svojom stvari. Prema navedenom sadržaju nije dužan trpjeti da druga osoba, protiv njegove volje, uporabi njegovu stvar na bilo koji način, pa tako i na način da na njegovo zemljište postavi skele i sl., a radi izvođenja radova na drugoj nekretnini. Pritom bez postojanja općih i zakonskih ograničenja vlasnik ima isključivo pravo posjedovanja, uporabe, korištenja i raspolaganja svojom stvari, i u tom smislu pravo na zaštitu prava vlasništva od smetanja posjeda, od oduzimanja posjeda i uznemiravanja. Dakle, bez u sudskom postupku uspostavljenog prava uporabe imao bi pravo na sudsku zaštitu svoga prava vlasništva. To znači da nije dužan trpjeti protiv svoje volje, da druga osoba uporabi njegovu stvar na bilo koji način, pa tako i da ovlaštenik prava uporabe koristi njegovo zemljište (postavi skele, prolazi stanom ${ }^{4} \mathrm{i}$ sl.), a radi izvođenja radova na svojoj nekretnini.

Iz toga razloga zahtjev za ostvarivanje prava uporabe tuđe nekretnine i glasi na nalaganje trpljenja obvezniku toga prava uporabe svoje nekretnine radi izvođenja radova. $^{5}$

Osim općih ograničenja prava vlasništva protiv volje vlasnika, vlasništvo se

4 Sudska praksa, alineja 1. objavljena uz čl. 107. ZV-a, u: Žuvela, Mladen, Vlasničkopravni odnosi (Zagreb: Informator, 2009.), 311.

5 Tako u presudi Županijskog suda u Slavonskom Brodu posl. br. Gž-1437-10 od 29. listopada 2015.:

Tuženik dužan je trpjeti da tužitelj postavi skelu na nekretnini upisanoj u z. k. ul. i to kč. br. 3 kuća broj 3 i dvorište na... i koristi tuženikovu nekretninu u dužini od 18,50 mi širini do 3 $m$, uz sjeverni zid tužiteljeve zgrade koja se nalazi na nekretnini upisanoj u z. $k$. ul. i to kč. br. stambeno poslovna zgrada broj 5 i dvorište u Ulici..., radi žbukanja i postavljanja fasade na sjevernom zidu te zgrade, te da tužitelj Ž. B. izvede limarske radove potrebne radi sanacije na sjevernom zidu svoje zgrade postavljanjem limenog krovnog opšava, koji sprječava prodor padalina s krovova drvarnice i garaže tuženika na sjeverni zid garaže tužitelja. Tužitelj dužan je izvesti radove iz točke I presude na sjevernom zidu svoje zgrade u roku od 15 dana računajući od dana od početka radova, u koji rok se ne uračunavaju dani kada izvođenje radova nije moguće zbog vremenskih prilika. 
može ograničiti i na temelju posebnih ograničenja iz čl. 32 . ZV-a i to radi zaštite interese sigurnosti, države, prirode, ljudskoga okoliša, zdravlja kao i na stvarima od interesa za RH koji je propis odlučan u smislu razmatranja uporabe radi izvođenja radova iz razloga što je zakonodavac predvidio istu vrstu naknade u slučaju oduzimanja (potpunog izvlaštenja) ili ograničenog osnivanja nekog drugog prava (nepotpunog izvlaštenja) kao i u slučaju uporabe tuđe nekretnine radi izvođenja radova, odnosno u oba slučaja vlasniku pripada pravo na primjerenu naknadu koja ne može biti manja od one koja bi mu pripadala da je provedeno nepotpuno izvlaštenje. ${ }^{6}$

\section{OVLAST UPORABE RADI IZVOĐENJA RADOVA KAO SUSJEDSKO PRAVO}

Ovlast uporabe radi izvođenja radova propisana je kao i druga susjedska prava radi uzajamnog obzirnog izvršavanja prava vlasništva. Zakonsko je ograničenje prava vlasništva koje po svom sadržaju ovlašćuje svoga nositelja da sa stvari u svom vlasništvu, pa tako i nekretninom, čini od nje što ga je volja te da isključi svakoga drugog od toga.

Susjedska su prava ovlasti vlasnika nekretnine koje ga ovlašćuju da u svezi s izvršavanjem svoga prava vlasništva zahtijeva od osobe koja je vlasnik druge nekretnine da ona u njegovu interesu trpi, propušta ili čini u odnosu na svoju nekretnine ono što je određeno zakonom. ${ }^{7}$

\section{NAČELA SUSJEDSKIH PRAVA}

\subsection{Načelo uzajamnog obzirnog izvršavanja prava vlasništva}

Susjedska su prva utvrđena radi uzajamnog obzirnog izvršavanja prava vlasništva. U tom smislu i uporaba tuđe nekretnine radi izvođenja radova treba biti vršena obzirno, odnosno u opsegu i vremenu koje će najmanje ograničavati prava vlasništva vlasnika poslužne nekretnine.

Budući da je ovo načelo primjenjivo na sva susjedska prava, pa tako i na služnosti koje su puno češće predmet sporova, dok su sporovi u pogledu prava uporabe tuđe nekretnine radi izvođenja radova dosta rijetki, bogatiju sudsku praksu o tome što je obzirno izvršavanje prava češće nalazimo u presudama o pravu služnosti. ${ }^{8}$

Susjedska prava, pa i pravo uporabe radi izvođenja radova, moraju se vršiti uz

6 Čl. 107. st. 3. ZV-a: za uporabu zemljišta iz st. 1 ovog članka... na zahtjev vlasnika nekretnine koja je privremeno uporabljena plaća se primjerena naknada, koja ne može biti manja od one na koliku bi imao pravo ako je bilo provedeno nepotpuno izvlaštenje njegova zemljišta.

7 Čl. 100. st.1.ZV-a.

8 Tako se u presudi Vrhovni sud Republike Hrvatske, br. Rev-2666/1999-2 od 30. travnja 2003. u pogledu obzirnog postupanja navodi: Stoga, iako je predloženi pravac izgradnje pristupnog puta manje komotan za tuženike kao vlasnike povlasnog dobra, ipak se njime omogućuje tuženicima izravan pristup na vlastitu nekretninu s postojećeg javnog puta, koji prolazi uz tu nekretninu isto kao i uz nekretninu tužitelja, pa nema valjanog razloga da tužitelji trpe provoz $i$ prolaz tuženika preko svoje nekretnine samo zato što je to za tuženike lakše i bolje. 
što veću pažnju i što manje oštećivanje opravdanih interesa opterećene osobe.

Nadalje, ograničenje vlasništva moguće je ustvrditi samo ako postoji opravdani interes. Pritom u slučaju uporabe tuđe nekretnine radi izvođenja radova predstavlja činjenicu da su ti radovi nužni i potrebni za korištenje i uporabu povlasne nekretnine.

Zahtjev za trpljenje i propuštanje vlasničkih prava može se ostvariti u postupku pred sudom, ako nije predviđen drugi put. ${ }^{9}$

\subsection{Načelo minimalnog zadiranja u pravo vlasništva}

Ovim je načelom propisano da je susjedska prava dopušteno izvršavati samo u mjeri i na način da se time što manje ograničava, opterećuje ili uznemirava onoga tko treba što trpjeti propustiti ili činiti.

\section{TKO JE DUŽAN TRPJETI, OGRANIČENJA PRAVA VLASNIŠTVA U OSTVARIVANJU SUSJEDSKIH PRAVA, PA TAKO I OSTVARIVANJE PRAVA UPORABE RADI IZVOĐENJA RADOVA}

Osim vlasnika nekretnine trpljenje, propuštanje ili činjenje može se zahtijevati, umjesto njega i od onoga tko posjeduje nekretninu na temelju prava izvedenog iz njegova. ${ }^{10}$

Obveze i ovlaštenja na temelju susjedskih prava vlasnika zemljišta vrijede odgovarajući i za vlasnike ostalih nekretnina i etažnih vlasnike, ako nije suprotno zakonu ili naravi nekretnine. ${ }^{11}$

\section{POSTUPAK OSTVARIVANJA PRAVA UPORABE}

Iz čl. 100. st. 2.ZV-a proizlazi da se ostvarivanje prava na uporabu tuđe nekretnine radi izvođenja radova, radi uzajamnog obzirnog izvršavanja prava vlasništva može ostvariti samo u postupku pred sudom ako nije predviđen drugi put zaštite.

Dakle, radi ostvarivanja prava uporabe tuđe nekretnine radi izvođenja radova nužno je, kada je to protiv volje vlasnika poslužne nekretnine, pokrenuti sudski postupak tužbom, pred nadležnim sudom.

Budući da je riječ o sporovima u kojima se odlučuje o vlasničkim pravima, obvezama i ovlaštenjima, isključivo je nadležan sud na čijem se području nalazi nekretnina. ${ }^{12}$

9 Sud je nadležan, a ne tijelo uprave, odlučiti o zahtjevu susjeda da mu se dopusti privremena uporaba tuđeg zemljišta - sudska praksa objavljena uz čl. 107. ZV-a, u: Žuvela, Vlasničkopravni odnosi, 312-313.

10 Čl. 100. st. 4. ZV-a.

11 Čl. 100. st. 5. ZV-a.

12 Čl. 56. st. 1. Zakona o parničnom postupku, Narodne novine, br. 53/91., 91/92., 112/99., 88/01., 117/03., 88/05., 2/07., 84/08., 123/08., 57/11., 148/11., 25/13., 28/13., 70/19. (dalje: ZPP). 


\section{STRANKE U POSTUPKU}

U sudskom postupku, koji se vodi radi uporabe nekretnine radi izvođenja radova, tužitelj je vlasnik povlasne nekretnine, tj. nekretnine na kojoj je nužno obaviti radove koji su potrebni za njezinu uporabu, kao ovlaštenik prava. Tuženik je vlasnik zemljišta, odnosno druge nekretnine kao poslužne, koji je dužan trpjeti privremenu upotrebu svog zemljišta, tj. nekretnine, postavljanjem skele ili upotrebe na drugi način.

Kako je ranije navedeno, trpljenje, propuštanje i činjenje može se zahtijevati umjesto od vlasnika i od posjednika nekretnine koji svoj posjed izvodi iz prava vlasništva vlasnika nekretnine. ${ }^{13}$

U tom smislu, obveznici privremene uporabe mogu biti, osim vlasnika kao osobe koja ima faktičnu vlast na stvari i koja je njen posjednik, i osobe koje stvar posjeduju kao plodouživatelji, založni vjerovnici, zakupoprimci, najmoprimci, čuvari, ili osobe koje su u nekom drugom odnosu u kojem su prema drugom ovlašteni ili obvezni u nekom vremenu posjedovati stvari, kao i posjednik pravne stvarne služnosti, kao i suposjednici. ${ }^{14}$ Može se zaključiti da tuženik može biti i vlasnik zemljišta, odnosno vlasnik ostalih nekretnina, i umjesto njega, navedeni krug osoba koji posjeduje nekretninu.

Dakle, tužitelj može kao tuženike naznačiti ili vlasnika ili izvedenoga posjednika, odnosno tužbom ne mora obuhvatiti i jednog i drugog.

Ako je više suvlasnika nekretnine odnosno zemljišta, koja suvlasnička zajednica nije pravno razdijeljena, ili je riječ o vlasništvu zajedničkih dijelova zgrade te zemljišta koje služi njezinoj redovitoj uporabi na strani tuženika, tužbom je potrebno obuhvatiti sve suvlasnike, budući da se tužbenim zahtjevom nalaže trpljenje, propuštanje ili činjenje koje u tom slučaju treba obvezivati svakog od suvlasnika kao obveznika toga prava.

Na pitanje može li se smatrati, ako se na strani tužitelja kao ovlaštenika prava uporabe odnosno vlasnika povlasne nekretnine nalazi više suvlasnika ili je dio na kojem je potrebno izvesti nužne i korisne radove zajednički dio zgrade ili zemljište koje služi redovitoj uporabi zgrade, ${ }^{15}$ gdje su svi suvlasnici jedinstveni i nužni suparničari, npr. u sporu radi utvrđenja prava služnosti ${ }^{16}$ ili se s obzirom na svrhu ostvarivanja prava uporabe, a to je izvođenje radova potrebnih za uporabu ili korištenje zgrade, da je riječ o izvršavanju ovlasti s obzirom na cijelu nekretninu u kojem se slučaju u pogledu ostvarivanja prava na uporabu, ovisno o vrsti i opsegu radova, primjenjuju odredbe čl. 85., 86., 87. i 93. ZV-a, analizirajući sudske prakse, pri pisanju ovoga rada, nije pronađen jednoznačni odgovor.

Vezano za dio zahtjeva koji se odnosi na naknadu počinjene štete i obvezu dovođenja poslužne nekretnine u stanje u kojem se nalazila prije toga (dalje: uspostava prijašnjeg stanja), suvlasnici povlasne nekretnine odgovaraju vlasniku poslužne

13 Čl. 1. st. 4. ZV-a.

14 Čl. 10. st. 3. ZV-a.

15 Čl. 62. st. 1. ZV-a: svaki zajedničar ima pravo glede cijele stvari postavljati protiv svakog one zahtjeve koje može postaviti vlasnik stvari.

16 Tako u odluci Rev-2459/17-2 od 31. listopada 2017. i Rev x 955/10 od 30. listopada 2012. 
nekretnine kao solidarni dužnici. ${ }^{17}$ Svaki solidarni dužnik odgovara vjerovniku za cijeli dug, odnosno vjerovnik može zahtijevati njegovo ispunjenje od koga hoće sve dok dug ne bude potpuno ispunjen. Obveza prestaje kada jedan dužnik ispuni dug i oslobađaju se svi dužnici.

\section{TUŽBENI ZAHTJEV}

Zahtjev u postupku ostvarivanja prava uporabe tuđe nekretnine radi izvođenja radova kondemnatoran je budući da se njime nalaže tuženiku trpljenje radnji koje je na njegovoj nekretnini ovlašten poduzeti tužitelj kao ovlaštenik prava uporabe. Takav tužbeni zahtjev mora obuhvaćati opis, vrste i opseg radova, kao i njihovo trajanje, koji moraju biti u tolikoj mjeri određeni da kod dobrovoljnog ispunjenja ili ovrhe ne dovode u pitanje sadržaj toga trpljenja. ${ }^{18}$

Pritom valja istaknuti kako presuda kojom se tuženiku nalaže trpljenje stječe svojstvo ovršnosti, bez proteka roka za dobrovoljno ispunjenje, čim postane pravomoćna. ${ }^{19}$

S obzirom na sadržaj odredbe st. 2. čl. 107. ZV-a proizlazi kako tužbeni zahtjev osim uz zahtjev da se tuženiku naloži trpljenje izvođenja radova treba obuhvatiti i obvezu tužitelja da čim prestane potreba za nekretninom, tuženiku ju treba dovesti u stanje u kojem se nalazila prije toga i naknaditi mu štetu. Sudska je praksa zauzela stajalište da taj dio zahtjev mora biti obuhvaćen i u tužbenom zahtjevu i u izrijeci presude kojom se dopušta uporaba nekretnine odnosno nalaže trpljenje tih radnji vlasnika povlasne nekretnine. ${ }^{20}$

U praksi se često susreću tužbe podnesene po čl. 107. ZV-a koje ne obuhvaćaju dio tužbenog zahtjeva iz čl. 107. st. 2. ZV-a, u cijelosti ili djelomice, odnosno najčešće ne sadrži i dio zahtjeva u pogledu dužnosti naknade štete, već eventualno vraćanja nekretnine u prijašnje stanje. To vjerojatno iz razloga što tužitelji nemaju pravni interes sami sebi nalagati obvezu vraćanja nekretnine tuženika u prijašnje stanje i naknade štete i zbog toga što taj dio tužbenoga zahtjeva u trenutku podnošenja tužbe

17 Čl. 43. Zakona o obveznim odnosima, Narodne novine, br. 35/05., 41/08., 125/11., 78/15., 29/18. (dalje: ZOO).

18 Sudska praksa navedena uz čl. 107., u: Žuvela, Vlasničkopravni odnosi, 312: Naime kad sud tuženiku izrekom odluke nalaže određeno trpljenje ono mora u svom sadržaju, predmetu, vrsti,opsegu i vremenu biti toliko određeno da se u slučaju dobrovoljnog ispunjenja ili ovrhe ne dovodi u pitanje sadržaj tog trpljenja, čl. 26. Ovršnog zakona, Narodne novine, br. 112/12., 25/13., 93/14., 55/16. i 73/17. (dalje: OZ).

19 Čl. 25. st. 2. OZ-a.

20 Sudska praksa navedena uz čl. 107., u: Žuvela, Vlasničkopravni odnosi, 312.

Prvostupanjski sud je, međutim propustio voditi računa o tome da je onaj tko upotrijebi tuđu nekretninu za potrebe svoje nekretnine dužan čim prestane potreba za takvom upotrebom, stvar dovede u stanje u kojem se nalazila prije radova te počinjenu štetu nadoknaditi po općim propisima za naknadu štete, a to sve mora biti sadržano u tužbenom zahtjevu i izreci presude, na što upućuje $i$ žaliteljica... To znači da je sud bio dužan pozvati tužitelja da postavi tužbeni zahtjev tako da bude određen i izvršiv te da u njemu bude sadržana i obveza tužitelja da stvar vrati u prijašnje stanje i tuženici naknadi eventualno nastalu štetu. Tako u presudi Županijskog suda u Zagrebu, Gž-5684/00, od 27. ožujka 2001. 
nije dospio.

Naime, da bi tužitelj zakonito izveo radove na tuđoj nekretnini, dužan je ishoditi ili dopuštenje vlasnika poslužne nekretnine izvan sudskog postupka ili, ako se protivi ili zbog drugih razloga nedostaje jasno očitovanje volje da se takvi radovi dopuštaju (nedostupnost vlasnika poslužne nekretnine i sl.), ovlaštenik je prava navedene radove dužan izvesti tek po pravomoćnosti presude u opsegu i vremenu u kojem mu se dopušta takva upotreba.

To znači da u trenutku podnošenja tužbe još nije započeo izvoditi radove niti je moguće znati hoće li biti potrebno da nekretninu nakon uporabe vrati u prijašnje stanje ni hoće li pritom nastati kakva šteta.

Budući da je u praksi zauzeto stajalište o tome da je riječ o zakonom propisanom sadržaju tužbenoga zahtjeva, kada tužbeni zahtjev nema sve propisane dijelove, s njim bi se trebalo postupiti kao s nepotpunim podneskom. ${ }^{21}$

Opravdanje za takvo pravno stajalište nalazi se $u$ tome što je pravo uporabe tuđe nekretnine iznimno tegobno i ograničavajuće u pogledu vlasništva poslužne nekretnine. Stoga je u istom postupku vlasniku takve nekretnine potrebno pružiti najveći opseg sudske zaštite, tako da je istodobno utvrđena dužnost ovlaštenika prava uporabe da čim prestane potreba, dovede poslužnu nekretninu u stanje u kojem se nalazila prije toga (prijašnje stanje), a počinjenu štetu naknadi po općim propisima o odgovornosti za štetu.

Sadržaj takve sudske odluke, međutim, ako ovlaštenik prava uporabe dobrovoljno ne ispuni svoju dužnost da nekretninu vrati u prijašnje stanje i naknadi počinjenu štetu, neće pružiti vlasniku poslužne nekretnine mogućnost ostvarivanja prava na naknadu štete na temelju iste, budući da izrijeka takve presude neće obuhvaćati ni predmet ni vrstu i opseg ispunjavanja obveze, pa u smislu čl. 29. st. 1. OZ-a nije podobna za ovrhu. Stoga se postavlja pitanje, je li nametanjem obveznog sadržaja tužbe u smislu čl. 107. st. 2. ZV-a, tuženiku pružan viši stupanj pravne zaštite od onoga koji mu pruža zakon, odnosno je li nametanjem obveze tužitelju obveznoga sadržaja tužbenog zahtjeva, pod prijetnjom odbačaja tužbe, ako takav zahtjev nije postavljen, razmjeran pruženoj pravnoj zaštiti tuženika.

21 Tako u presudi Županijski sud u Varaždinu, Gž-2843/16, od 3. siječnja 2017.: Tijekom postupka provedenim očevidom na licu mjesta sud je utvrdio da žlijeb nije popravljen, da se popravak može izvršiti jedino ulaskom u dvorište tuženika koju činjenicu niti tuženici u žalbi na prvobitno donesenu presudu u ovom postupku ne osporavaju $i$ da se mjesto gdje je potrebno izvršiti popravak odnosno zamjenu žlijeba nalazi na otprilike 8 metara gledajući od ulaza u dvorište tuženih, zbog čega i smatra da postoje uvjeti propisani čl.107. Zakona o vlasništvu i drugim stvarnim pravima da se i tuženoj naloži trpljenje s time da je tužiteljica dopunom $i$ ispravkom tužbe tužbeni zahtjev sredila navodeći način na koji će se izvršiti popravak, opseg uporabe, rok vršenja radova, obvezala se otkloniti svu eventualno nastalu štetu i dovesti nekretninu tužene u stanje prije provedenih radova. 


\section{NAKNADA ŠTETE}

Ako su pojedini radovi izvedeni na temelju pravomoćne presude, kojom je ovlašteniku toga prava dopuštena uporaba tuđe nekretnine, ili je on protupravno to zemljište uporabio pa je riječ o naknadi koja vlasniku uporabljene nekretnine pripada zbog uznemiravanja vlasništva činom izvođenja radova koji su poduzeti prije ili bez dopuštenja, ${ }^{22}$ pripada mu pravo na naknadu štete po općim propisima o odgovornosti za štetu, ${ }^{23}$ bez obzira na krivnju, odnosno po kriteriju uzročnosti.

Po njemu se ne traži niti jedan oblik krivnje u konkretnom slučaju vlasnika povlasne nekretnine za štetu nastalu pri izvođenju radova na poslužnoj nekretnini.

Prema općim načelima naknade štete po kriteriju uzročnosti oštećenik mora dokazati štetnu radnju i štetu, a ne krivnju štetnika. Takve radnje, ako je šteta nastala izvođenjem radova na temelju pravomoćne presude ili druge sudske odluke (npr. privremene mjere), iako su radnje kojom je prouzrokovana šteta, nisu protupravne.

Također budući da je zakonom propisna dužnost popravljanja štete kao u čl. 107. st. 2. ZV-a, a u vezi s izvođenjem radova iz čl. 107. st. 1. ZV-a, moglo bi se smatrati da postoji pretpostavljeni kauzalitet. To znači da bi obveznik prava uporabe, koji je u postupku radi naknade štete tuženik, trebao dokazati da nastala šteta nije u uzročnoj vezi s izvedenim radovima. Pritom se postavlja pitanje je li kauzalitet i apsolutan? U tom se slučaju tuženik kao štetnik nikako ne bi mogao osloboditi odgovornosti, pa ni kod više sile, krivnje samoga oštećenika i sl. ${ }^{24}$

U takvom postupku vlasnik poslužne nekretnine kao tužitelj trebao bi dokazati opseg i visinu nastale štete, koju je vlasnik povlasne nekretnine koji je izvodio radove dužan nakaditi. Iz sadržaja propisa proizlazi da se nalaže potpuna naknada u konkretnom slučaju imovinske štete nastale na poslužnoj nekretnini izvođenjem radova $\mathrm{i}$ to uspostavom prijašnjeg stanja (dovođenjem nekretnine u stanje prije uporabe) ili novčanom naknadom, odnosno i kumulacijom oba načina. ${ }^{25}$

To bi najčešće u slučaju izvođenja radova postavljanjem skele ili, npr. izvođenjem radova s krova poslužne nekretnine i sl. značilo prvenstveno vraćanje poslužne nekretnine u stanje prije uporabe, uklanjanjem skela, izravnavanje terena ili, npr. vraćanjem crjepova na krov, kupnju novih crjepova i zamjenu oštećenih, popravkom nastalih oštećenja na poslužnoj nekretnini. Naknada imovinske štete bila bi u novčanom obliku, npr. naknada za električnu energiju ili vodu s trošila poslužnog dobra ako pristup priključku na povlasnom dobru nije bio moguć, naknada vrijednosti građevinskoga materijala i troškova radova ugradnje u poslužnu nekretninu koje je snosio vlasnik poslužne ako vlasnik povlasne to nije učinio, kao i naknada izmakle koristi, ako, npr. vlasnik poslužnu nekretninu nije mogao iznajmljivati tijekom izvođenja radova.

22 Čl. 167. st. 3. ZV-a.

23 Čl. 1045. ZOO-a.

24 Gorenc, Vilim, Zakon o obveznim odnosima s komentarom (Zagreb: RRIF, 1998.), 216, komentar uz čl. 155.

25 Čl. 1085. ZOO-a. 


\section{PRIMJERENA NAKNADA}

Osim naknade imovinske štete $\mathrm{i}$ bez obzira na to je li nastala, vlasnik privremeno uporabljene nekretnine ima pravo i na primjerenu naknadu za njezinu uporabu. ${ }^{26}$ Ona se dosuđuje samo na zahtjev vlasnika nekretnine.

Naknada ne može biti manja od one na koliku bi imao pravo da je provedeno nepotpuno izvlaštenje njegovog zemljišta. To znači da bi mogla biti određena i u višem iznosu, ako to opravdavaju okolnosti slučaja, ali ne i u nižem od propisanog.

O naknadi za nepotpuno izvlaštenje, kao što je ranije rečeno govori odredba čl. 33. st.1. ZV-a i u njoj je navedeno da u slučaju nepotpunog izvlaštenja vlasnik ima pravo na naknadu prema propisima o izvlaštenju. Važeći propis o izvlaštenju je Zakon o izvlaštenju i određivanju naknade. ${ }^{27}$

Zakon o izvlaštenju u pogledu nepotpunog izvlaštenja predviđa institut utvrđivanja zakupa ili služnosti, no to predviđa i institut privremenog uzimanja u posjed susjedne nekretnine. ${ }^{28}$

Sudska praksa sadržajno pravo uporabe u smislu čl. 107. st. 1. ZV-a u pogledu primjerene naknade, izjednačila je sa sadržajem privremenog uzimanja u posjed susjednih nekretnine, a za koju je propisna istovrsna naknada, kao i za zakup. Stoga se u sudskom postupku dosuđuje naknada kao za zakup zemljišta predviđena čl. 52. st. 1. i 2. ZOI-a, koja dospijeva danom stupanja u posjed. ${ }^{29}$

\section{ZAKLJUČAK}

Istražujući temu uporabe tuđe nekretnine radi izvođenja radova uočava se kako navedeni institut nije često bio predmetom sudskih sporova. To navodi na zaključak da su vlasnici nekretnina u ostvarivanju susjedskih prava skloni postizanju sporazuma, odnosno da i bez prisilnog izvršenja koriste svoja vlasnička prava tako da drugima ne štete, odnosno da postupaju obzirno i prema tuđim interesima. Stoga se možemo i nadati da ono nije posljedica protupravnih postupanja koja nisu sankcionirana $u$ sudskom postupku.

S obzirom na nedavne događaje potresa koji su izazvali veliki broj oštećenja

26 Čl. 107. st. 3. ZV-a.

27 Narodne novine, br. 74/14., 69/17., 98/19 (dalje: ZOI).

28 Čl. 8. st. 1. ZOI-a.

29 Tako u presudi Vrhovni sud Republike Hrvatske, Revx-46/11-2 od 9. ožujka 2011. Na temelju tih utvrđenja nižestupanjski sudovi su ocijenili, da je tuženik kao vlasnik nekretnine na kojoj su se obavljali radovi radi izgradnje njegove poslovne zgrade, upotrijebio tuđu odnosno nekretninu tužitelja za potrebe takve izgradnje, pa je dužan vlasniku te upotrijebljene nekretnine platiti primjerenu naknadu, sukladno odredbi čl. 107. st. 1. i 3. ZV-a. Prema odredbi čl. 107. st. 1. i 3. ZV-a vlasnik nekretnine koji je za potrebe izvođenja radova upotrijebio tuđe zemljište, dužan je vlasniku nekretnine koju je koristio, platiti primjerenu naknadu, koja ne može biti manja od naknade za nepotpuno izvlaštenje. Prema čl. 5., 38. i 39. Zakona o izvlaštenju, Narodne novine, br. 9/94., 35/94., 112/00., 114/01. (dalje: ZI) određeno je da se nepotpunim izvlaštenjem smatra privremena upotreba susjedovoga zemljišta radi izgradnje objekta ili izvođenja drugih radova, o čemu je riječ u konkretnom slučaju, s tim da se naknada za to korištenje utvrđuje u visini zakupnine koja se postiže na tržištu. 
na nekretninama na većem području Republike Hrvatske, za očekivati je i povećanje potrebe za korištenjem navedenog instituta, radi izvođenja nužnih radova za uporabu i korištenje nekretnina. To se pokazuje dosta složenim postupkom, s obzirom na mogući veći broj stranaka, količinu činjenica koje je nužno dokazati, kao i da je u postupku najčešće potrebno provesti vještačenja radi dokazivanja koji su radovi nužni za uporabu i korištenje te da se na drugi način ne mogu izvesti.

Za te je postupke za pretpostaviti da su često i hitne naravi budući da je riječ o izvođenju radova na nekretninama, pa bi ih, uz dobro poznavanje materijalnog prava i procesnih odredaba te sudske prakse, trebalo provesti što brže i učinkovitije. Odgovor na pitanje hoće li tome tako i biti dat će nam sudska praksa u nadolazećem razdoblju.

\section{LITERATURA}

1. Europska konvencije za zaštitu ljudskih prava i temeljnih sloboda, Narodne novine, Međunarodni ugovori, br. 18/97., 6/99. - pročišćeni tekst, 8/99., 14/02., 13/03., 9/05., 1/06., 2/10. i 13/17.

2. Gorenc, Vilim. Zakon o obveznim odnosima s komentarom. Zagreb: RRIF, 1998.

3. Ovršni zakon, Narodne novine, br. 112/12., 25/13., 93/14., 55/16., 73/17.

4. Protokol broj 1. Konvencije za zaštitu ljudskih prava i temeljnih sloboda, Narodne novine, Međunarodni ugovori, br. 18/97., 6/99., 14/02, 13/03., 9/05., 1/06., 2/10.

5. Ustav Republike Hrvatske, Narodne novine, br. 56/90., 135/97., 8/98., 113/00., 124/00., 28/01., 41/01., 55/01., 76/10., 85/10. i 5/14.

6. Vrhovni sud Republike Hrvatske, Rev-2666/1999-2, od 30. travnja 2003.

7. Vrhovni sud Republike Hrvatske, Revx-46/11-2 od 9. ožujka 2011.

8. Zakon o izvlaštenju i određivanju naknade, Narodne novine, br. 74/14., 69/17., 98/19.

9. Zakon o izvlaštenju, Narodne novine, br. 9/94., 35/94., 112/00., 114/01.

10. Zakon o obveznim odnosima, Narodne novine, br. 35/05., 41/08., 125/11., 78/15., 29/18.

11. Zakon o parničnom postupku, Narodne novine, br 53/91., 91/92., 112/99., 88/01., 117/03., 88/05., 2/07., 84/08., 123/08., 57/11., 148/11., 25/13., 28/13., 70/19.

12. Zakon o vlasništvu i drugim stvarnim pravima, Narodne novine, br. 91/96, 68/98, 137/99, 22/00, 73/00, 114/01, 79/06, 141/06, 146/08, 38/09, 153/09, 90/10, 143/12, 152/14.

13. Županijski sud u Slavonskom Brodu, Gž-1437-10, od 29. listopada 2015.

14. Županijski sud u Varaždinu, Gž-2843/16, od 3. siječnja 2017.

15. Županijski sud u Zagrebu, Gž-5684/00, od 27. ožujka 2001

16. Žuvela, Mladen. Vlasničkopravni odnosi. Zagreb: Informator, 2009. 


\section{Lidija Bošnjaković*}

\section{Summary \\ USE OF ANOTHER PARTY REAL PROPERTY FOR PERFORMANCE OF WORKS}

The paper presents the use of the institute of using someone else's real property for the purpose of performing works as a right of property in court practice. In doing so, the author sought to draw attention to the most common problems that arise in the conduct of such proceedings, which proved to be complex given the mandatory content of the claim, and sought to provide answers to certain legal questions.

Keywords: use of another party real property for performance of works; obligor; right holder, damage; appropriate compensation.

* Lidija Bošnjaković, dipl. iur., Judge of County Court in Zagreb; lidija.bosnjakovic5@gmail. com. ORCID: https://orcid.org/ 0000-0001-7517-9947. 